\title{
Immunological Effect of Amritadi Kwath For Improving Immunity To Fight Covid -19 Pandemic
}

\author{
Dr. Brajeshwar Mishra
}

Director, Satyananda yoga and Ayurveda Research, Institute Motihari, East Champaran, Bihar.,PIN -855401

DOI: 10.29322/IJSRP.10.08.2020.p104102

http://dx.doi.org/10.29322/IJSRP.10.08.2020.p104102

\begin{abstract}
COVID -19 is a respiratory disease caused by a coronavirus ( SARS Cov-2). Coronaviral proteins is responsible to disrupt the immune response pathway and breakdown the immune system. In Ayurvedic system of medicine Amritadi Kwath may be effective for immunity booster drug to healthy people for improving immunity to fight COVID -19 pandemic . But Amritadi Kwath to be used freshly prepared, and shelf life is ( $1 / 2-1$ day). Which is major drown back of Amritadi Kwath to the large scale production.

In this perspective it is an urgent need to Randomized double blind placebo controlled trial of Amritadi Kwath formulated Ghana satva converted in to AMRITA Tablet form on COVID -19 positive patient for more improving immunity to fight COVID -19 pandemic.
\end{abstract}

Index Terms- Amritadi kwath, Gnana satva, Amrita Tablet, covid-19, immunomodulator.

\section{INTRODUCTION}

$\mathrm{C}$ OVID -19 is a respiratory disease caused by a coronavirus ( SARS Cov -2). Coronavirus is enveloped virus with a positive sense, single -stranded RNA genome.The coronaviral genome encode four major structural proteins, the spike (S) protein, nucleocapsid $(\mathrm{N})$ protein, membrane $(\mathrm{M})$ protein, and the envelope (E) protein, all of which are required to produce a structurally complete viral particle .

The coronavirus disease (COVID -19 is highly transmittable and pathogenic viral .Coronaviral proteins is responsible to disrupt the immune response pathway and breakdown the immune system. In the absence of effective inhibition patient suffer prograssive immunological damage and develop upper respiratory infection(URTIs).Lower respiratory tract infection (LRTIs) and severe acute respiratory syndrome (SARS). Currently there are no approved therapeutic agent available for coronavirus.

Thus there is an urgent public health need for rapid development of novel interventions.

Ayurveda is the natural system of health care all over the World. Ayurvedic medicines as the major remedy in traditional medical system, have been used in medical practice for thousands of years and have made a great contribution to maintaining human health.

Ministry of AYUSH recommended the self care guideline for prevention health measures and boosting immunity with special reference to respiratory health. In this perspective AMRITDI KWATH may be immunity booster drugs. Amritadi Kwath which mainly constituent of Guduchi. Tinospora Cordifolia willd Hook f \& Thomus, Ashwagandha Withania Somnifera L. Dunal, Yashtimadu Glycyrrhiza glabra Linn,Tulshi Ocimum sanctum Linn, Pipali piper longum linn.

Guduchi Tinospora cordifolia has been reported to benefit the immune system and successfully immunomodulator efficiency ( K. G. C. Dissanayake. et. al 2020) Extract of T cordifolia has also may be effective in immunodeficiency virus. (HIV) (Kaliker MV. et. al 2008) Ashwagandha Withania Somnifera Withania has been reported to benefit to immune system and immunomodulatory activity (.Davis. L. et. al 2000. P. Amaravati et. al 2012)Yashtimadhu Glycyrrhiza glabra has been reported that immunomodulatory activity ( Papaya Mitra muzamder et. al 2012, Kashif Hussein et. al 2017 )Tulsi Ocimum sanctum has been reported to immunomodulatory activity ( C. R. jaba et. al 2011, Gayatri Nahak et. al 2014)and Pipali Piper longum has been reported to immunomodulatory activity (E.S.sunala et. al 2004) Satyapal Singh et. al 2015 has been reported that Guduchi leads to immunomudulator by activating the lymphocytes, Tulsi act by modulating the humoral immunity, Ashwagandha act immunomodulating cellular immunity, Pippali works via modulation of both specific and non specific immune response .Yashtimadhu also evaluated for its anti-viral activity against HIV, validating its immunomodulatory effect.

Thus prepared Amritadi Kwath to clinical trial on healthy people for talking as an immunity booster drug to protect transmittable coronaviral infection.

\section{MATERIAL AND METHOD}

\section{Procurement and preparation of plant material.}

The crude drugs mentioned in Bhavaprakasha Nighantu ( Indian Materia Medica).The preparation of AMRITADI KWATH were taken from the pharmacy of Ravindra Nath Mukharje

Ayurveda college and Hospital Motihari,after proper authentication by the Department of pharmacognosy of the Institute. Then, the physical impurities were removed and drugs were washed with water, sorted and sun dried below $450 \mathrm{oc}$. Dried drugs were stored in tightly closed containers. The crude drugs used in Amritadi Kwath with their botanical identities and parts used are given in Table -1 


\section{Table -1 Crude drugs of Amritadi Kwath}

$\begin{array}{llc}\text { Botanical } & \text { Fam } & \text { Part used } \\ \text { Name. } & & \\ \text { Tinospora cordifolia. } & \text { Menispermaceae. } & \text { Stem. } \\ \begin{array}{l}\text { Guduchi } \\ \text { Withania Somnifera. }\end{array} & \text { Solanaceae. } & \text { Root. } \\ \begin{array}{l}\text { Ashwagandha } \\ \text { Glycyrrhiza glabra. }\end{array} & \text { Fabaceae. } & \text { Root } \\ \begin{array}{l}\text { Yastimadhu } \\ \text { Ocimum sanctum } \\ \text { Tulsi }\end{array} & \text { Labiatae } & \text { Leaf. } \\ \begin{array}{l}\text { Piper longum. } \\ \text { Pipali }\end{array} & \text { Piperaceae. } & \text { Fruit. }\end{array}$

Preparation of AMRITADI KWATH

Preparation of AMRITADI KWATH to be considered flowing pharmaceutical Factors.

Vessel for Amritadi Kwatha,Proportion of water, Temperature, Particle size of Amritadi KwathDravyas (Drugs used for decoction),Duration of heating, and Analytical study of Amritadi Kwatha.

1 Vessel to be used for Amritadi Kwath---Vessel imparts a specific role in Amritadi Kwath

preparation. In ancient time earthen pot was used having qualities such temp regulation, alkaline in nature, doesn't take part with chemical reaction with ingredients which are under processing. Also due to its narrow opening it can control vapors within hence the important active principles can be saved. Now a day stainless steel vessel can used due to easy availability, less costly and easy for maintenance.

2. Proportion of water -- proportion of water to be added for Amritadi kwath preparation is important factor.Different proportion of water $(4,8$ and 16) mentioned in classic depends on the hardness as well as on quantity of the drug used.Some Acharya has mentioned that the proportion of water may be decided on the basis of the quantity of drug taken.However, most of the times, it is difficult to judge the consistency of drugs, especially when the contents are poly herbal. Hence, an emergence need is required for qualitative and quantitative study to standardized quantum of heat and time duration.

3.Temperature --Regulation of temperature protects heat labile phytoconstituents. Madhyamagni is the term used to denote mild-to-moderate heat in preparation of kwath. Temperature holds the significant factor in preserving thermolabile active constituent Therefore, during the preparation of Amritadi Kwath temperature may be maintained between 85 and $90^{\circ} \mathrm{C}$.

4 Particle size --In conventional method of Kwath exact particle size of raw drugs is not mentioned. Most of the scholars use powder of raw drugs as Yavkut churna (Coarse powder). Mostly 60-100 size can preferred for Amritadi Kwath purpose.

5.Duration of heating--

One fourth and one eighth of original volume of water are the terms used in ancient methods of Kwath preparation. The degree of heating depends on Laghutwa (Easy to digest) and Gurutwa (Hard to digest) of Amritadi Kwath,

On the basis of above principle the authenticated crude drugs were crushed to a coarse powder separately and then mixed

thoroughly with 8 parts of water in a stainless steel container and then continuous mild heat was applied until it was reduced to onefourth of its initial quantity. During the heating process, continuous stirring was done to facilitate the evaporation and avoid any deterioration due to burning of materials. After a desirable reduction in volume was achieved, the Kwatha was filtered through single folded cotton cloth and collected in a separate Vessel. Amritadi Kwath were subjected to various analytical parameters as Organoleptic parameters, Physicochemical parameters and phytochemical screening parameters.

\section{Clinical aspect}

I have selected 50 healthy people for clinical trial of Amritadi Kwath .Out of 50 healthy people 40 were male and 10 people female, the age varied from 18 to 70 years. I have applied 20 ML to 40 ML Amritadi Kwath daily for 2 week.

\section{RESULT}

The Organoleptic characters of Amritadi Kwath were the following :

Rupa(color) was dark brown, Rasa (taste) was bitter, Ganda (odor) was characteristics due to the specific properties of the various ingredients and sparsha (consistency / texture) of Amritadi Kwath was liquid as given in Table -2

\section{Table -2 Organoleptic parameters of Amritadi Kwath.}

Parameters.

Color.

Taste.

Odor.

Form.

$\mathrm{pH}$ of the Amrita Kwath was $4.53 \pm 0.03$, loss on drying in Amrita Kwath was $3.4 \pm 0.20 \%$ w/w

as given in Table 3 .

\section{Table -3 Physico-chemical parameters of Amritadi Kwath.}

\section{Parameters.}

$\mathrm{PH}$ at $5 \%$ equeous solu

Lass on drying at $110 \mathrm{oc}(\% \mathrm{w} / \mathrm{w})$

Specific gravity.

Total solid content. (\%w/w)

Ash valu.

Acid insoluble Ash.

Methanol soluble extractive. (\%w/v)

The number in parentheses indicate the number of sample / determination carried out.

Preliminary phytochemical screening reveals the presence of tannins, alkaloids, saponins, glycosides and flavonoids etc. in the Amritadi Kwath. given in Table 4

\section{Table - 4 Preliminary phytochemical screening of Amritadi Kwath.}

$\begin{array}{llc}\text { Phytoconstituents } & \text { Test performed } & \text { Results } \\ \text { Tannins. } & \text { Ferric chloride test. } \quad+ \\ \text { Alkaloids } & \text { Dragendroff's test. } \quad+\end{array}$


Flavonoids. Glycosides

Steroids.

Terpenoids.

Anthraquinones.

$\mathrm{NaOH}$ Solution test. keller-Killani test. $\quad+$ Lieberman's test. $\quad+$

Salkowski's test. $\quad+$

Benzene test.

(+) Denotes presence of Phytochemical

(-) Denotes Absence. of Phytochemical

\section{Observation}

At the end of 2 week It can be observed that the people realize the natural stamina,strength and ability of the body, mind emotions, and in some people the body weight positively increased. It can Observed that Fever, cough, difficulty breathing tiredness, Nasal congestion, runny nose, sore throat, and severe disease as Asthma, bronchitis, pneumonia. etc did not appearance after 12 week used of Amritadi kwatha.

\section{DISCUSSION}

On proper investigative search, it has been seen that Amritadi kwatha becomes base material for most of the available dosage forms among Ayurvedic medicaments. Hence, to establish our assumption, literature and research papers with probable possible dosage forms were searched where Amritadi Kwatha acts as base material and it can thoroughly explored with the advantage of these dosage forms in the context of their effectiveness and safety,but they are to used in fresh state due to less stability, inconvenience to prepare fresh Amritadi Kwath every time needed etc.

The Comparative study of Amritadi Kwath, I observed that the process of the Ghana satva is considered to be similar to the aqueous extraction of the drug. It is considered to contain all the active principle as that of the whole drug. So advantage in using Ghana satva it higher concentration, lower dosage, and longer shelf life.

Thus Amritadi Kwath formulated Ghana satva converted in to AMRITA TABLET form may be increase the self life make it higher concentration, lower dosage, better bio availability and easy to dispense for dose fixation. Prepared Amritadi Kwath formulated Ghana satva Converted into AMRITA Tablet following procedure.

\section{Preparation of AMRITA TABLET.}

The Amritadi Kwatha can boiled again over slow fire on a gas stove, maintaining the temperature between $90^{\circ} \mathrm{C}$ and $95^{\circ} \mathrm{C}$ till a semisolid consistency is obtained. As the water evaporates, the viscosity of the extract increases, resulting in Ghana satva form. Then, the Ghana satva can mixed with the Churna of Amritadi Kwath (up to $10 \%$ of extract) further forming a solid mass.

The solid mass (Ghana satva) can forced through a no. 16 sieve and granules were prepared and then dried at $50^{\circ} \mathrm{C}$ in a hot air oven for 10 hours. The dried granules were passed again through a no. 20 sieve. The formulation can then compressed in a single-punch tablet press with a target weight of $500 \mathrm{mg}$.

The Amrita Tablet can subjected to various analytical parameters as follows.
Organoleptic

parameters,Physico-chemical parameters,Quantitative tests for tablet as Weight variation test, tablet hardness test, tablet disintegration time and friability.Qualitative tests for various functional groups.

Chromatographic analysis: Thin layer chromatography (TLC) High performance liquid chromatography ( HPLC), Nuclear magnetic resonance spectroscopy (NMR), Mass Spectrometry (MS) and Heavy metal analysis, pesticide residue value, Microbial overload and fungal growth study can carried out. Afterwords to determine acute toxicity test and long term toxicity test on animals species for assessing the safety of AMRITA Tablet as follows.

\section{Acute toxicity test}

Animal species ---Rodents species can be selected.

Sex --- Male and female mice can be used

Number of Animals ----Each testy Group can consist of last five per sex.

Route of administration -- oral root

Dose level ---- A sufficient number of dose label can be used in mice to determine the appropriate lethal Dose.

Duration of study --Duration of acute toxicity test evaluation seven to fourteen days.

Observation ----Toxic signs and the severity on set progression and reversibility of the signs can be obsessed and recorded in relation to dose and time. Mice during the observation period can be autopsied. If necessary a histopathological examination can be conducted on organ or tissue showing microscopic change of autopsy.

\section{Long term toxicity test}

Animal species --Rodents species can be selected.

Sex -- Male and female mice and rats can be use.

Number of Animals ---Each test group can consist of at least five mice per sex and three rats per sex.

Route of Administration ---Oral root.

Administration period --The period of administration of the test substance to mice and rats will depend on the expected period of clinical use.

Observations and examinations

Observation and examination can be performed on the following items.

1 General signs, body weight and water intake.

2 Haematological examination.

3 Renal and hepatic function tests.

4 Other Function test.

5. Animals found dead during the examination can be autopsied as soon possible. A macroscopic examination can be made of Organdy and tissues.

6 . In order to maximize the amount of useful information that can be obtained during the administration period, all moribund animals can be sacrificed tether than allowed to die. period to sacrifice, clinical observation can be recorded and blood sample collected for haematological and blood chemical analysis.

Recovery from toxicity . 
Then evaluate the immunological efficacy of AMRITA Tablet on COVID-19 positive For improving immunity to fight COVID -19 Pandemic, as follows.

\section{Human Pharmacology (phase l)}

The objective of the safety in this phase is the estimation of safety and tolerability with the initial administration of Amrita Tablet on Covid -19 Positive. In this phase can be applying Amrita Tablet in healthy volunteers and certain type of patients.

Maximum tolerated dose -- To determine the tolerability of the dose range expected to be needed for later clinical study and to determine the nature of adverse reaction can be expected

\section{Therapeutic Exploratory Trial ( Phase II )}

Therapeutic exploratory trial ( phase 11 )--studies on a limited number of COVID -19 positive patient to determine clinical efficacy and to further confirm safety. This trial can be preferably designed as randomized, double -blind, controlled study, using for control groups either an alternative treatment or a placebo.

The objectives of phase ll study can include evaluation of potential study endpoints, therapeutic regimens and target populations ( mild versus severe disease) for further study.

Therapeutic Confirmatory Trial ( phase III) Therapeutic confirmatory trial ( phase 11l)-A larger COVID -19 positive patient group can usually study a randomized double blind design to validate preliminary evidence of efficacy obtained in earlier study.

Study in phase -lll can designed to confirm the preliminary evidence accumulated in phase 11 , that AMRITA TABLET is safe and effective then can be use in the intended indication and recipient population

\section{CONCLUSION}

It is my concussion that Amritadi Kwath may be effective immunity booster for improving immunity. Amritadi Kwath may be act on improving vitality, mental faculties and promoting longevity.

Amritadi Kwath has no adverse side effect and other complications even long term use in therapeutic dose. In this conclusion I would like to say that there is an urgent need to Randomized double blind placebo controlled trial of Amritadi Kwath formulated Ghana satva converted in to AMRITA Tablet form on COVID -19 positive patient for more improving immunity to fight COVID -19 pandemic.

Institutional Ethics committee has approved for conducting clinical trial of Amrita Tablet on COVID -19 positive patient. After receiving CTRI Number by Clinical Trials Registry - India. ICMR-

National Institute of Medical statistics, Will be Conducting clinical trail.

\section{REFERENCES}

[1] Master Protocol A Mult-centre,Adaptive, Randomized, Double -Blind placebo controlled clinical trial of the safety and efficacy of investigational
Therapeutics for the Treatment of COVID -19. Version Number 2.0. February 2020.www.who.int/ blueprint /priority /key -action.

[2] 2 .Dewald schoeman et.al Coronavirus envelope protein : Current Knowledge, schoeman and fielding virology journal 2019 ,south Africa.

[3] 3. Sri Bhava Mishra of Bhavaprakasha Nighantu Commentary by Dr. C. K. Chunekar, Varanasi chaukhamba bharti Academy publication 2002.

[4] 4. Database of Medicinal plant use in Ayurveda. Volume -2 page -500,. Volume -3 page $-88,256,472$, and 561. Published by Central Council for Research in Ayurveda and siddha. Department. Of ISM Ministry of Health and Family welfare Govt. of India. 2005

[5] 5 K. G. C. Dissanayake, W.P.R.Tperara and N. Premasinghe, Immunomodulatory efficiency of Tinospora cordifolia against vital infection. World journal of Pharmaceutical and medical Research, 2020,6(5) 22-28.

[6] 6. M. V. Kalikar, V. R Thawani, U. K. Varadpande Immunomodulatory effect of Tinospora cordifolia extract in Human immunodeficiency virus (HIV) positive patients. Journal of pharmacology . Vol-4 issue -3. 2008

[7] 7. L. Davis , Girijaw kuttan, immunomodulatory activity of Withania somnifera Journal Ethnopharmacology .2007. 71(1-2) 193-200.

[8] 8. P. Amarawatti , Ch.srilatha , V. Ramadevi and K. Sujata, Immunomodulatory effect of Withania somnifera (Ashwgandha) against Fenvalerate induced immunotoxicity. International Journal of pharma and Bio science.2012. Volume -3 Issue 1 pages 10-16.

[9] 9. Papaya Mitra Muzamder, Parmaguru Rathinavelusamy, Evaluation of immunomodulatory Activity of Glycyrrhiza glabra L root in combination with zing. Asian Pacific Journal of Tropical Bio Medicine volume -2 issue -1 supplement January 2020.

[10] 10. Kashif Hussein, zafer Iqbal, Rao zohidi Muhammad kahan and Mahomumod Kashif salami, Immunomodulatory activity of Glycyrrhiza glabra against mixed Eimeria infection in chicken. International journal of Agriculture and Biology . 2017. Vol-19 .No -4

[11] 11.C.R.jaba , R. Vaidyanathan,immunomodulatory activity of aqueous extract of Ocimum sanctum in rat. International journal on pharmaceutical and Bio Medical Research 2011,Volume. 2(1).

[12] 12. Gayatri Nahak Rajani kanta sahy, immunostimulatory effect of Ocimum sanctum Linn leaf extract in clarias Batrachus Linn. Asian Journal of pharmaceutical and clinical Research 2014. Volume-7 issue -3.

[13] 13. E.S. Sunila, G. Kuttan immunomodulatory and anti tumar Activity of piper longum Linn and piperine, Journal of Ethnopharmacology ,2004

[14] 14. satayapal Singh, P. S Byadi, J. S. Tripathi and N. P Rai. Clinical appraisal of immunomodulators in Ayurveda in the light of Recent Pharmacological advance. World Journal of pharmaceutical Research, Volume -4, issue -4, 2015.

[15] 15. Charka samhita sutra chapter 4 ,commentary by Brahmanand Tripathi, chaukhamba surbharati prakashn Varanasi 1996

[16] 16. Sharangdhra samhita Madhyama Khanda ch. 2 Varanasi : choukhmbha surbharati publication, 2004.

[17] 17.Vandana meena, Shanti Bhutan, Amanda K chaudhary. Kwatha kalpana : It's versatility with probable Advancement : Asian journal of pharmaceutics. Oct-Des 2017 ( suppl) 11.(4) s 678.

[18] 18. Sushma Dongre, shishir pande, Need and approach of Pharmaceutic standardization of Kwath kalpana in present scenario -A critique. International journal of Ayurveda and pharma Research. March 2016 volume 4 Issue 3.

[19] 19 . Umapatic .C. Baragi, Pramod C .Baragi, and Vinay J. Shukla, Standardization and Quality control parameters of Dashanga Kwath Ghana Tablet : An Ayurvedic formulation. International Journal of Ayurveda Research Jan- March 2011, 2(1)-42-47.

[20] 20. Harsh Pandya, Rohit sharma, P. K. Prajapati Standardization and Quality Control parameters of Dushmoola Kwath Granules for instant use an Ayurvedic formulation. American international Journal of contemporary scientific Research 2014.

[21] 21. The Ayurvedic pharmacopeia of India part 1. vo- ix first Edition Govt Of India. Ministry of AYUSH 2016.

[22] 22. Volume 1 General Guidelines for Drug Development of Ayurveda Formulation, Volume 2. General Guidelines for Safety /Toxicity Evaluation of Ayurvedic formulation, and Volume 3 General Guidelines for clinical Evaluations of Ayurvedic intervention. Published by Central Council for Research in Ayurvedic Sciences. Ministry of AYUSH. Govt. Of India. New Delhi. 2018.

This publication is licensed under Creative Commons Attribution CC BY 
Champaran, Bihar, PIN -855401, E-mail -

dr.brajeshwarmishra@mail.com, Mob No-- ～+918969127251

\section{AUTHORS}

First Author - Dr. Brajeshwar Mishra, Director, Satyananda yoga and Ayurveda Research, Institute Motihari, East 